\title{
First record of the irregular sea urchin Lovenia cordiformis (Echinodermata: Spatangoida: Loveniidae) in Colombia
}

\author{
C. G. Muñoz ${ }^{1 *}$ and E. Londoño-Cruz ${ }^{1,2}$
}

\begin{abstract}
Background: A first record of occurrence of the irregular sea urchin Lovenia cordiformis in the Colombian Pacific is herein reported.

Results: We collected one specimen of Lovenia cordiformis at Gorgona Island (Colombia) in a shallow sandy bottom next to a coral reef. Basic morphological data and images of the collected specimen are presented. The specimen now lies at the Echinoderm Collection of the Marine Biology Section at Universidad del Valle (Cali, Colombia; Tag Code UNIVALLE: CRBMeq-UV: 2014-001).

Conclusions: This report fills a gap in and completes the distribution of the species along the entire coast of the Panamic Province in the Tropical Eastern Pacific, updating the echinoderm richness for Colombia to 384 species.
\end{abstract}

Keywords: Lovenia cordiformis, Loveniidae, Sea porcupine, Heart urchin, Gorgona Island

\section{Background}

Heart shape-bodied sea urchins also known as sea porcupines (family Loveniidae), are irregular echinoids characterized by its secondary bilateral symmetry. Unlike most sea urchins, features of the Loveniidae provide different anterior-posterior ends, with mouth and anus located ventrally and distally on an oval-shaped horizontal plane. Sea porcupines are infaunal burrowers, small to medium-sized and detritus feeders usually restricted to dwell within sand and coarse rubble (Kanazawa 1992), therefore, can be considered rare and hard to find alive. Lovenia cordiformis Agassiz 1872, belongs to a genus comprising less than 20 living species, which along with other five living genera (e.g. Echinocardium), engross the family Loveniidae. The species, belonging to the Order Spatangoida, is a phylogenetic member of the most diverse extant group of echinoids as exposed by Stockley et al. (2005). Since its description by Agassiz in 1872, $L$. cordiformis has been considered native to the Eastern Pacific, and with this paper we report the occurrence of L. cordiformis in a coral reef of an island on the

\footnotetext{
* Correspondence: carlos.g.munoz@correounivalle.edu.co

${ }^{1}$ Department of Biology, Coral Reefs Ecology Research Group, Universidad del Valle, Cali, Colombia

Full list of author information is available at the end of the article
}

continental shelf of the Pacific coast of Colombia, filling in a gap of its coastal distribution in the Tropical Eastern Pacific (TEP).

\section{Materials and methods}

One Lovenia cordiformis specimen was collected on October 19, 2012 by snorkeling during low tide at approximately $2.5 \mathrm{~m}$ deep, close to a Malacanthus brevirostris burrow in the outer border of La Azufrada $\left(2^{\circ} 57^{\prime} 22.4^{\prime \prime} \mathrm{N}-78^{\circ} 10^{\prime} 28^{\prime \prime} \mathrm{W}\right)$, a 9.4 ha protected coral reef in Gorgona Island (TEP) (see Zapata and VargasAngel 2003; for detailed description). This specimen is the first to be collected in the Colombian Pacific, and was identified using Brusca (1980), Hickman (1998), Kerstitch and Bertsch (2007), and the online database of Kroh and Hansson (2013). Dr. Gordon Hendler (curator of echinoderms at the Natural History Museum of Los Angeles County, CA.) confirmed the identification with photographs of the collected specimen taken when still alive.

We trapped the specimen unintentionally while digging the substrate for the collection of sand samples. At first and due to its appearance and color, the specimen remained unnoticed until it began to move. The specimen was fixed in ethanol (95\%), identified at the laboratory 
and deposited in the Echinoderm Collection of Universidad del Valle (in Cali, Colombia; Tag code UNIVALLE: CRBMeq-UV: 2014-001).

\section{Results and discussion Systematics}

Class ECHINOIDEA Leske, 1778.

Order SPATANGOIDA Claus, 1876.

Suborder MICRASTERINA Fischer, 1966.

Family LOVENIIDAE Lambert, 1905.

Genus Lovenia Desor, 1847.

Lovenia cordiformis Agassiz, 1872.

The specimen had the typical shape of heart urchins, with a larger length $(46.50 \mathrm{~mm})$ than width $(35.83 \mathrm{~mm})$, and a height of $20.72 \mathrm{~mm}$ with a flat oral surface. The convex dorsal surface was covered by small brown hair-like spines, which gives the animal the appearance of a coconut shell. There were evident scattered long serrated spines with a clear banded coloration pattern of brown-reddish and pale-yellowish bands. These scattered spines run backward along the longer axis, as if they were combed (Fig. 1).

Considering the size of the specimen and the holes dug in the substrate where it was found, the specimen

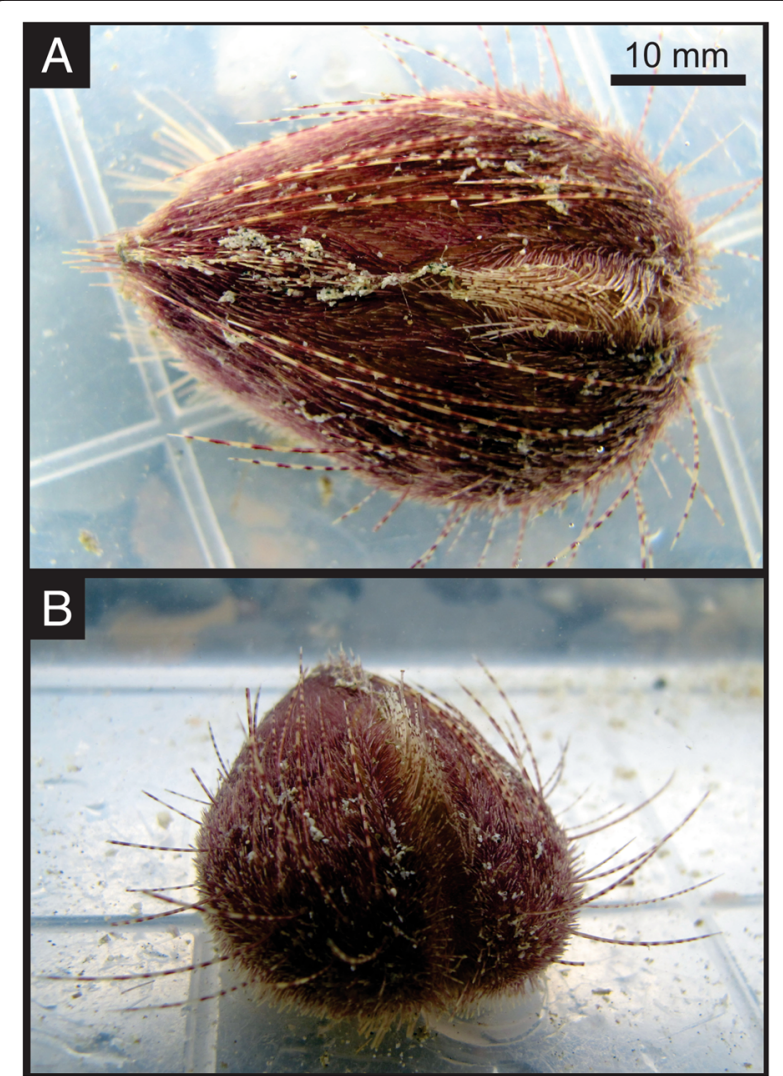

Fig. 1 Dorsal (a) and frontal (b) view of Lovenia cordiformis collected at La Azufrada reef (Gorgona Island, Pacific coast of Colombia). Scale bar: $10 \mathrm{~mm}$ should had been dwelling within the first $15 \mathrm{~cm}$ deep in the sandy substrate. The substrate consisted on runoff land-sediments with calcareous sands and coral rubble mixture, where some scattered living coral Pocillopora spp. colonies are found unattached along with massive colonies like Pavona spp. and Gardineroseris planulata.

Despite Mortensen's monography (1951), who reported the continental distribution of $L$. cordiformis including Ecuador, the distribution of the species as depicted in different available online resources (e.g. World Echinoidea Database) only places the species in southern California, around the Peninsula of Baja and along the coast of Panama. With this report and according to our review of available data, the updated geographical distribution of the species includes the coasts of Southern California, Mexico, Panama and Colombia, and the oceanic islands Coco and the Galapagos (Maluf 1988; Lessios 2005; Honey-Escandón et al. 2008; Cortés 2012), while no records are reported for Malpelo Island, where the geomorphology (mostly rocky walls and the lack of shallow sandy bottoms), may hinder its occurrence.

Following the recent review by Benavides-Serrato et al. (2013) and this new record, the echinoderm richness in Colombia now totals 384 species, of which $32.6 \%$ (125 spp.) inhabits the Pacific coast, with Gorgona Island reaching 42 species. It seems that these echinoids are fairly rare, or at least, this is the case for the Colombian Pacific. For example, there is only one related genus listed for Colombia (see Homolampas hastata -now accepted as Aerolampas hastata- in Cohen-Rengifo et al. 2009); hence, this report constitutes the first national record for the genus Lovenia and the second for Loveniidae.

\section{Conclusions}

This is the first record of the species L. cordiformis in Colombia, filling a gap of its distribution in the Eastern Pacific region. It is clear that despite the efforts, knowledge and basic ecological information about echinoderms and infaunal communities in the Colombian Pacific and the region is still incomplete.

\section{Acknowledgements \\ We are thankful to Gordon Hendler for the confirmation of the specimen and to National Natural Parks of Colombia for their constant support related to our studies, especially PNN Gorgona and the Henry von Prahl scientific research station. CG Muñoz field activities were co-funded by COLCIENCIAS and Universidad del Valle in Cali, Colombia (Project code: 1106-489-25135).}

\section{Authors' contributions}

CGM collected the specimen and drafted the manuscript. ELC identified the specimen and improved the manuscript. Both authors read and approved the final manuscript

Competing interests

The authors declare that they have no competing interests. 


\section{Author details}

'Department of Biology, Coral Reefs Ecology Research Group, Universidad del Valle, Cali, Colombia. ${ }^{2}$ Department of Biology, Rocky Intertidal and Shallow Subtidal Ecosystems Research Group, Universidad del Valle, Cali, Colombia.

Received: 16 March 2016 Accepted: 12 April 2016

Published online: 01 May 2016

\section{References}

Agassiz A. Preliminary notice of a few species of Echini. Bull Mus Comp Zool. 1872;3:55-8

Benavides-Serrato M, Borrero-Pérez GH, Cantera JR, Cohen-Rengifo M, Neira R. Echinoderms of Colombia. In: Alvarado JJ, Solís-Marín FA, editors. Echinoderm research and diversity in Latin America. Berlin Heidelberg: Springer; 2013. p. 145-82.

Brusca RC, Tucson AZ. Common intertidal invertebrates of the Gulf of California. 2nd edition. The University of Arizona Press. 1980.

Cohen-Rengifo M, Bessudo S, Soler G. Echinoderms, Malpelo Fauna and Flora Sanctuary, Colombian Pacific: new reports and distributional issues. Check List. 2009;5(3):702-11.

Cortés J. Marine biodiversity of an Eastern Tropical Pacific oceanic island, Isla de Coco, Costa Rica. Rev Biol Trop. 2012;60 Suppl 3:131-85.

Hickman CP. A field guide to Sea Stars and other Echinoderms of Galápagos. 1st ed. Sugar Spring Press: Lexington; 1998.

Honey-Escandón M, Solís-Marín FA, Laguarda-Figueras A. Equinodermos (Echinodermata) del Pacífico Mexicano. Rev Biol Trop. 2008;56 Suppl 3:57-73. Kanazawa K. Adaptation of test shape for burrowing and locomotion in Spatangoid echinoids. Palaeontology. 1992;35(4):733-50.

Kerstitch A, Bertsch H. Sea of Cortez marine invertebrates. a guide for the Pacific Coast, México to Perú. 2nd ed. Monterrey: Sea Challengers; 2007.

Kroh A, Hansson H. Loveniidae. In: Kroh A, Mooi R, editors. World Echinoidea database. 2013. http://www.marinespecies.org at VLIZ. Accessed 21 Feb 2014.

Lessios HA. Echinoids of the Pacific Waters of Panama: status of knowledge and new records. Rev Biol Trop. 2005;53:147-70.

Maluf LY. Composition and distribution of the Central eastern Pacific echinoderms. Natural History Museum, Los Angeles County, Technical Report. 1988;2:1-242.

Mortensen TH. A Monograph of the Echinoidea. V, 2. Spatangoida II. Amphisternata II. Spatangidae, Loveniidae, Pericosmidae, Schizasteridae, Brissidae. Copenhagen: C.A. Reitzel; 1951.

Stockley B, Smith AB, Littlewood T, Lessios HA. Phylogenetic relationships of spatangoid sea urchins (Echinoidea): taxon sampling density and congruence between morphological and molecular estimates. Zool Scr. 2005;43(5):447-68.

Zapata FA, Vargas-Angel B. Corals and coral reefs of the Pacific coast of Colombia. In: Cortés J, editor. Latin America coral reefs. Amsterdam: Elsevier Science; 2003. p. 419-47.

\section{Submit your next manuscript to BioMed Central and we will help you at every step:}

- We accept pre-submission inquiries

- Our selector tool helps you to find the most relevant journal

- We provide round the clock customer support

- Convenient online submission

- Thorough peer review

- Inclusion in PubMed and all major indexing services

- Maximum visibility for your research

Submit your manuscript at www.biomedcentral.com/submit

) Biomed Central 